\title{
Performance Appraisal and Employee Commitment in Abia State Civil Service: A Focus on Ministries of Education and Works
}

\author{
Onyemaechi Uchenna \\ Department of Management, \\ Abia State University, Uturu, Nigeria. \\ Agu Godswill Agu \\ Department of Marketing, \\ Abia State University, Uturu, Nigeria. \\ Uche Emmanuel Uche \\ Department of Economics, \\ Abia State University, Uturu, Nigeria.
}

\begin{abstract}
This work focused on performance appraisal and employee commitment in Abia State Civil Service. The dynamic nature of employees' commitment to their Ministries made this investigation very necessary. The objectives of the study were; to find out whether objective evaluation of employee performance has a positive relationship with employee affective commitment, to ascertain whether subjective evaluation of employee performance has relationship with employee continuance commitment. To achieve this objective, a survey research design was adopted. The techniques employed in analyzing the data were descriptive statistics and Pearson Correlation Coefficient. The results indicated that objective evaluation of employee performance has positive relationship with employee affective commitment. It was also found that subjective evaluation of employee performance has a weak and in significant relationship with employee continuance commitment. The study concluded that objective evaluation of employee performance has a positive relationship with employee affective commitment and subjective evaluation of employee performance has a weak relationship with employee continuance commitment in Ministries of Education and Works Umuahia. It was recommended that Directors/managers of public sector should ensure that performance criteria are clearly spelt against which employees at any level of management is appraised to ensure objectivity in the assessment.
\end{abstract}

Keywords: performance appraisal, employee commitment, civil service.

\section{INTRODUCTION}

Performance appraisal is a periodic evaluation of employee's performance measured against the job's stated or presumed requirements and is one of the basic tools that make workers to be very effective and active at work. In the view of Singh, Kochar \& Yuksel (2010) performance appraisal is one of the most important functions of Human Resource managers. It is concerned with identifying, measuring, influencing and developing job performance of employees in the organization in relation to the set norms and standards for a particular period of time in order to achieve various purposes. Employees are required to generate a total commitment to desired standards of job performance and improved job performance for sustaining profitable growth for the organization and long-term value creation for the customers. This involves getting optimum use of the available knowledge, skills and abilities in the workforce to optimize employee productivity and give an organization a competitive advantage. 
The purpose of performance appraisal is to assess employees' performance as objectively as possible. The results of the performance appraisal are used in setting the direction for the individual performance development by bringing out both performance strengths and weaknesses and subsequently developing action plan to facilitate the desired development (Anne, Poti \& Isaac, 2013). Onoh (2008:202), sees performance appraisal as a formal assessment of how well employees are performing their job. It may also be defined as any procedure that involves setting work standard, assessing the employee's standard, and providing feedback to the employee with the aim of motivating that person to eliminate performance deficiencies or to continue to perform above par. Most managers may be unhappy with various facets of the performance appraisal process, but most would agree that they are nevertheless very important. One reason why appraisals are so important to organizations is that they provide a benchmark for assessing the extent to which recruitment and selection process is adequate. Organizations endeavor to recruit and select high-quality employees who are capable of working effectively towards the accomplishment of the organizational goals (Vignaswaran; 2005).

Furthermore, we have two types of performance appraisal namely: the open and confidential (closed) appraisal systems. In the open appraisal system, the appraisee is fully aware of the exercise as he is consulted and shown the report. This approach ensures freedom from bias and protects employees from prejudices and irrationality of superirors. This no withstanding, non-objectivity may creep in, as the raters may compromise with the appraisee due to some circumstances. In the confidential (closed) appraisal system, the rater works with the personal data of the appraisee and does not disclose appraisal reports to employees. This approach allows appraisers to rate employee performance purely on merit, minimizing needless argument and confrontations that are usually encountered in open systems between the appraiser and appraise. The major drawback in the closed appraisal system is that it provides a platform for raters to deal unjustly with employees who are not in their good books (Onoh, 2009).

The role of performance appraisal has gone beyond a tool for assessing employees to one that is used to reinforce the desired behavior and competent performance of the employees. Performance appraisal is the single most powerful instrument for mobilizing employees in a sophisticated and well managed organization in order to achieve strategic goals (Singh et al, 2010). It is a universal phenomenon which serves as a basic element of effective work performance which is essential for the effective management and evaluation of staff. It aims at improving the organizational performance as well as individual development. Performance appraisal is necessary to increase the performance of the employees and the organization to check the progress towards desired goals. Dattner (2010) expresses that a well designed performance appraisal system develops criteria for successful performance, give performance feedback and enable a more equitable reward system. Performance criteria form the basis of evaluating the employees' performance and their contribution towards the organization goal. It consists of the desired outputs expected of employees. Performance criteria should be aligned with goals, relevant to given roles, specific and measurable, under employees control and understood and accepted by participants.

\section{Statement of the Problem}

Performance appraisal is an unbiased evaluation of performance level of an organizational member or the process by which an organization obtains feedback about the effectiveness of their employees and is intended to reveal their areas of strength and weakness. This process is meant to help organizations determine employee rewards allocation, promotion, devise 
appropriate training and development programme or dismissal of employee. But most managers do not take this exercise serious as a result of that, they do not establish performance standards, objectives or adopt appropriate techniques that will help realize the objective of the exercise. Some organizations do not utilize the appraisal result for the purpose is meant for such as promotion, incentive, identification of training need and so on, rather employees are appraised subjectively ie some employees are favored by their boss in some cases at the expense of the key workers. This has led employees not to identify with their organization, its goals and wishes to maintain membership in that organization.

These problems have led to display of different types of commitment by employees in the organization, affective commitment is pre-requisite to achievement of organizational set goals and objectives while continuance commitment can hinder effectiveness of the organization and the achievement of organizational set goals and objectives to an extent. When the type of commitment displayed by an employee is not geared towards achievement of organizational objectives, its effect is not limited to the organization alone but the economy at large.

\section{Objectives of the Study}

1. To find out whether objective evaluation of employee performance has a positive relationship with employee affective commitment.

2. To ascertain whether subjective evaluation of employee performance has relationship with employee continuance commitment.

\section{Performance Appraisal}

\section{REVIEW OF RELATED LITERATURE}

Performance appraisal is an unbiased evaluation or assessment of performance level of an organizational member. In the view of Muo (2007), performance appraisal entails a systematic, organized and formalized process of evaluating individual employee's job related strengths and weaknesses with a view to providing feedback on which performance adjustment can be made. This concept has increasingly become part of a strategic approach to integrating human resource activities and business policies and may now be seen as a generic term covering a variety of activities through which organizations seek to assess employees and develop their competence, enhance performance and distribute rewards (Fletcher, 2001). Thus, both practice and research have moved away from a narrow focus on psychometric and evaluation issues to developmental performance appraisal (Levy \& Williams, 2004; Waal, 2003), which may be defined as any effort concerned with enriching attitudes, experiences, and skills that improve the effectiveness of employees (Boswell \& Boudreau, 2002).

Angelo \& Robert (2006) see performance appraisal as a discrete, formal, organizationally sanctioned event, usually not occurring more frequently than once or twice a year, which has clearly stated performance dimensions and/or criteria that are used in the evaluation process. Jackson \& Schuler (2002) described it as a formal process of employee monitoring which usually involves the evaluation of performance based on the judgments and opinions of subordinates, peers, supervisors, other managers and even workers themselves. De Waal (2004) asserts that performance appraisal is concerned with the clarification of employees' work expectations, helping individual employee grow and the collective growth of the entire workforce, as well as ensuring that pay structure incorporates performance. It also ensures that employees have an awareness of how organizations expect them to perform in relation to organizational goals after their performances are evaluated.

Manoharan, Muralidharan \& Deshmukh (2009) posit that performance appraisal is an important management tool to assess employee efficiency in the workplace, and may be 
defined as a structured formal interaction between a subordinate and supervisor that usually takes the form of a periodic review which could be annual or semi-annual to evaluate work performance. Performance appraisal is intended to engage, align, and coalesce individual and group effort to continually improve overall organizational mission accomplishment (Grubb, 2007). In some organization's appraisal results may be used to determine relative rewards in the firm who should get merit pay increases, bonuses, or promotions. Similarly, appraisal results can be used to identify the poor performers who may require some form of counseling, demotion, dismissal or decreases in pay. Interestingly, performance appraisal is a very controversial managerial issue.

It is also important to consider methods/techniques used in Performance appraisal exercise, and it has been expressed by Onoh (2009) that there is no universally accepted method of performance evaluation that fit every purpose, person or organization, rather, the techniques adopted vary from one organization to another and is the prerogative of the management. The methods have been classified into two; the traditional method and non-traditional method of performance appraisal. The traditional appraisal methods are: graphic rating scale, ranking method, essay method, checklist method, critical incident method and forced choice method while the non-traditional are as follows: behaviorally anchored rating scales (BARS), management by objectives (MBO), assessment centers and will be discuss in turn.

Ranking Method: The rater ranks all employees in order of merit from the best worker down to the worst. The method is based on the overall performance of the employee and his contribution to the organization. It is also useful when the result is used for making concrete personnel decisions, as it does not permit equal rating of employees. This method becomes practically impossible as the number of employees to be ranked become large.

Graphic Rating Scale (GRS): This method presents appraisers with a list of dimensions, which are aspects of performance that determine an employee's effectiveness. Examples of performance dimensions are cooperativeness, adaptability, maturity, and motivation. Each dimension is accompanied by a multi-point $(3,5$, or 7$)$ rating scale. The points along the scale are defined by numbers and/or descriptive words or phrases that indicate the level of performance. The midpoint of the scale is usually anchored by such words as "average," "adequate," "satisfactory," or "meets standards." (Kane \& Lawler,2009).

Many organizations use graphic rating scales because they are easy to use and cost little to develop. HR professionals can develop such forms quickly, and because the dimensions and anchors are written at a general level, a single form is applicable to all or most jobs within an organization. Graphic rating scales do present a number of problems, however. Such scales may not effectively direct behavior; that is, the rating scale does not clearly indicate what a person must do to achieve a given rating, thus employees are left in the dark as to what is expected of them. For instance, an employee given a rating of 2 on "attitude" may have a difficult time figuring out how to improve (Meyer, 2001).

Essay Method: Onoh (2009) asserts that evaluators using method gives an unstructured narrative report on the ratee's strengths, weakness and potentials. The exercise is usually carried out by someone who knows the individual very well, such as his supervisor or excoworker. An essay evaluation from the former employer carries a significant weight. In Nigeria, this technique is essentially a letter of recommendation from the last employer or referee. 
Critical Incident Method: This technique provides actual and factual data upon which judgement is based. It requires the supervisor to identify and record every significant positive or negative behaviours of employees as they occur. Examples of such behaviours are those that portray judgement, learning ability, dependability, accuracy of work. This method is potentially an effective method of performance evaluation; it provides an insight into determining employee suitability for promotion and it is also free from rating errors inherent in other methods (Onoh, 2009).

Behaviorally Anchored Rating Scales (BARS): Behaviorally Anchored Rating Scales (BARS) is a relatively new technique, which combines the graphic rating scale and critical incidents method. It consists of predetermined critical areas of job performance or sets of behavioral statements describing important job performance qualities as good or bad (for the qualities like inter-personal relationships, adaptability and reliability, job knowledge etc). These statements are developed from critical incidents. In this method, an employee's actual job behaviour is judged against the desired behaviour by recording and comparing the behaviour with BARS. Developing and practicing BARS requires expert knowledge. The specific purpose of the Behaviorally Anchored Rating Scale is to use behavioral procedures to design an instrument that can identify and measure the critical components that constitute effective performance in an occupation (Nwema \& Gachunga, 2014).

Management by Objective (MB0): This is a management system designed to achieve organizational effectiveness by steering each employee's behavior toward the organization's mission. The MBO process includes goal setting, planning, and evaluation. Goal setting starts at the top of the organization with the establishment of the organization's mission statement and strategic goals. The goal-setting process then cascades down through the organizational hierarchy to the level of the individual employee. An individual's goals should represent outcomes that, if achieved, would most contribute to the attainment of the organization's strategic goals. In most instances, individual goals are mutually set by employees and their supervisors, at which time they also set specific performance standards and determine how goal attainment will be measured (Lindsey, 2005).

Employee Commitment: In general sense employee commitment is the employee's psychological attachment or loyalty to the organization. Robbins and Coulter (2013) define employee commitment as the degree to which an employee identifies with a particular organization and its goals and wishes to maintain membership in that organization. Commitment is the bond an employee experiences with the organization, employees who are committed to their organization generally feel a connection with their organization, feel that they fit in and also feel they understand the goals of the organizations. Such employees tend to be more determined in their work, show relatively high productivity and are more proactive in offering their support.

In the view of Onoh (2009) organizational commitment signifies identifying with one's employing organization. It is a strong desire to remain a member of a particular organization; a willingness to exert high levels of effort on behalf of the organization and a definite belief in, and acceptance of, the values and goals of the organization (Monday, porter \& steers, 1982). Employee commitment can be Meyer \& Allen (1991) in Onoh (2009):

Affective Commitment: Relates to how much employees want to stay with their organization. If an employee is affectively committed to the organization, it means that he/she will want to stay with the organization. They typically identify with the organizational goals, feel that they fit into the organization and are satisfied with their work. Employees who are affectively 
committed feel valued, act as ambassadors for their organization and are great assets for organizations.

Continuance Commitment: Continuance commitment relates to how employees feel the need to stay with their organization, the underlying reason for employees continuance commitment is possibly lack of work alternative and remuneration. A good example of continuance commitment is when employees feel the need to stay with their organization because their salary and fringe benefits will not improve if they move to another organization. This can be an issue for an organization because employees that have continuance commitment may become dissatisfied with their work and yet, are unwilling to leave the organization.

Normative Commitment: Relates to how much employees feel they should stay with their organization. Normatively committed employees feel that leaving their organization would have disastrous consequences, and feel a sense of guilt about the possibility of leaving. Reasons for such guilt vary, but are often concerned with employees feeling that leaving the organization would create a void in knowledge/ Skills which would subsequently increase the pressure on their colleagues.

Based on this, we hypothesize thus:

$\boldsymbol{H}_{01}$ : Objective evaluation of employee performance has no positive relationship with employee affective commitment.

$\boldsymbol{H}_{\text {o2: }}$ Subjective evaluation of employee performance has no significant relationship with employee continuance commitment.

\section{THEORETICAL FRAMEWORK}

Theoretical perspectives suggested by the literature in relation to performance appraisal and employee commitment, which could provide explanation to the study are drawn from expectancy theory and this guided our study.

\section{Expectancy theory}

Victor Vroom propounded this theory in 1964, states that a person's motivation towards an action at any time is determined by an individual's perception that a certain type of action would lead to a specific outcome and his personal preference for the outcome. Expectancy is the probability that particular action will lead to a desired reward. Thus, if an individual has a particular goal, some behavior must be produced in order to achieve that goal. He will weigh the likelihood that various behaviors will achieve the desired goals and if certain behavior is expected to be more successful than others, that particular behavior will be preferred by the individual. Employees are motivated to put more effort so as to produce better results because of the expected reward.

\section{Empirical Studies}

Munir, Aziz \& Muhammad (2013) conducted a study on fairness of performance appraisal and organizational commitment. This study was conducted to examine the perception of public servants towards the fairness of performance appraisal and its effect on organizational commitment. This study also examined the intermediary effects of satisfaction in these two relationships. The data for this study were obtained through a survey among 425 employees of government agencies. The findings show that perceived fairness of performance appraisal has influenced their commitment towards organization through the mediating factor of satisfaction. This finding is consistent with the efforts by the government to establish a more transparent and more accountable decision-making process in an organization. The researcher 
conclude that, to make performance evaluation to be more effective in influencing organizational commitment, satisfaction of the civil servants as well as fair performance management within the organization should be given priority.

Ramous, Lavish, Zipporah \& Isaac (2016) examined the impact of performance appraisal on employees job satisfaction and organizational commitment; a case of microfinance institution in Ghana. Performance appraisal is credited by researchers as a tool for spurring employees towards the attainment of organizational goals. Considering employees' attitudes as a vital component in the attainment of organizational goals, this study investigated the impacts of performance appraisal on the job-satisfaction and commitment of employees. The study used a descriptive research design. A stratified random sampling was used to sample 200 respondents from Microfinance organizations in Ghana. The study used questionnaires as its data collection instrument. Regression Analysis and correlations were used to analyze the data collected. The study revealed that employees' job satisfaction is positively related to and impacted by fairness in the appraisal system, linking appraisals with promotion, clarity of roles and feedback about their performance. The study also revealed that employee commitment is positively related to and impacted by the linkage of appraisals with salary, identification of training needs, clarity of performance appraisal purpose and employee involvement in the formulation of appraisal tools. The study recommends that organizations comply with rewards systems linked to performance levels, provide training to employees identified to be in need of training so as to further enhance the relevance of performance appraisal, and also instigate and/or maintain communication between management staff and their subordinates especially with regards to their performance.

Neha \& Himanshu (2015) carried out a study on the impact of performance appraisal on organizational commitment and job satisfaction. The objective of their study was to find out the effect of performance appraisal system on job satisfaction and organizational commitment in the service sector in India. The study adopted an online questionnaire survey in collection of data. Correlation and regression analysis in SPSS package was used for the study and the results indicated that employees who were satisfied with the performance appraisal system of their organization were also satisfied with their job and were committed to their organization.

Vignaswaran (2008) conducted a study on the relationship between performance appraisal satisfaction and employee outcomes in peninsular Malaysia. The objectives of his study were to; examine the relationship between performance appraisal satisfaction and employee outcomes, in the form of work performance, affective organizational commitment and turnover intention and to explore the influence of intrinsic motivation as a mediating variable. Data were collected through the use of questionnaire and all the items were measured on a 5-point likert scale. The study used descriptive statistics for analyzing the demographic characteristic of the respondents while correlation analysis were used to measure the relationship between performance appraisal satisfaction, intrinsic motivation and work performance, affective organizational commitment and turnover intention.

The results revealed that the relationship between performance appraisal satisfaction and employee outcomes in the form of work performance, affective organizational commitment and turnover intention was mediated by employees' intrinsic motivation.

\section{METHODOLOGY}

A structured questionnaire was used to elicited information from employees' of selected Ministries (Education and Work in Umuahia, Abia State). The population of the study was seven hundred and sixty one (761) and Taro Yamane formula was used to derive the sample 
size, which is two hundred and sixty two (262). Bowley's formula was used to determine the number of questionnaire to administer to each strata. The instrument, made up of nine (9) items was subjected to reliability test using the Cronbach's alpha and the result is as shown below:

Reliability Statistics

\begin{tabular}{|c|c|}
\hline Cronbach's Alpha & N of Items \\
\hline .792 & 9 \\
\hline
\end{tabular}

Again, Pearson Correlation Coefficient in SPSS (statistical package for social sciences) was used in testing of the hypotheses.

\section{RESULT}

A total of two hundred and sixty two copies of the questionnaire were administered but two hundred and fifty seven were returned. This represents ninety eight response rate. The mean weighting of responses gathered from the questionnaire were computed and interpreted from the data and are presented in tables.

Table 1: Responses on whether objective evaluation of employee performance positively relate to employee affective commitment

\begin{tabular}{lccc}
\hline \multicolumn{1}{c}{ Options } & Frequency & Percentage & Mean \\
\hline Strongly disagree & 23 & 8.9 & 3.54 \\
Disagree & 45 & 17.5 & \\
Agree & 149 & 58.0 & \\
Strongly agree & 40 & 15.6 & \\
Total & 257 & 100.0 & \\
\hline
\end{tabular}

Source: Field survey data, 2018

Table 1 depicts the frequencies and percentages of the respondents on how objective evaluation of employee performance positively related to employee affective commitment. From the table, the total which captures number of respondent was 257. This means that 257 out of the 262 sample size were validly enumerated with the remaining 5 not used because of invalid information. For the analysis proper, 23 respondents representing $15.6 \%$ of the 257 valid respondents strongly disagreed that objective evaluation of employee performance has positive relationship with employee affective commitment in the ministry. Also, 45 respondents representing $17.5 \%$ of the entire respondent disagreed that objective evaluation of employee performance has positive relationship with employee affective commitment. On the other hand, 149 (58.0\%) and 40 (15.6\%) respondents agreed and strongly agreed respectively that objective evaluation of employee performance has positive relationship on employee affective commitment. This shows that most of the respondents accepted that objective evaluation of employee performance has positive relationship with employee affective commitment. To support this, the mean of 3.54 herein was greater than the minimum mean for acceptance of 3.00, confirming that most of the respondents accepted that objective evaluation of employee performance has positive relationship on employee affective commitment in the ministries. Based on the above discussions, the study asserts that objective performance evaluation of employees increases their affective commitment to their ministries. 
Table 2: Responses on whether subjective evaluation of employee performance has relationship with employee continuance commitment

\begin{tabular}{lccc}
\hline \multicolumn{1}{c}{ Options } & Frequency & Percentage & Mean \\
\hline Strongly disagree & 42 & 16.3 & 3.12 \\
Disagree & 72 & 28.0 & \\
Agree & 99 & 38.5 & \\
Strongly agree & 44 & 17.1 & \\
Total & 257 & 100.0 & \\
\hline
\end{tabular}

Source: Field survey data, 2018

Table 2 shows the respondent responses on whether subjective evaluation of employee performance has relationship with employee continuance commitment. As seen from the table $2,42(16.3 \%)$ and $72(28.0 \%)$ of the respondents strongly disagree and disagree respectively that subjective evaluation of employee performance has relationship with employee continuance commitment/evaluation of employees performance in the same level with different yardstick has significant relationship with employee willingness to stay with the ministries as a result of lack of work alternative. Conversely, 99 (38.5\%) and $44(17.1 \%)$ of the respondents agreed and strongly agreed that subjective evaluation of employee performance has relationship with employee continuance commitment.

To buttress this, the mean of 3.12 herein was greater than the minimum mean for acceptance of 3.00. This therefore implies that subjective evaluation of employee performance has relationship with employee continuance commitment in the ministries but a weak one.

\section{Test of Hypotheses Hypothesis One}

Table 3: Pearson correlation result for the relationship between objective evaluation of employee performance and employee affective commitment.

\begin{tabular}{ccc}
\hline Pearson correlation coefficient & Probability value & $\mathbf{N}$ \\
\hline 0.72 & $0.00^{*}$ & 257 \\
\hline
\end{tabular}

Source: Researcher's survey, $2018 . /^{*}=$ Significant at $1 \%, 5 \%$ and $10 \%$

The result presented on table 3 shows the Pearson correlation result for the objective evaluation of employee performance and employee affective commitment to their ministries. From the table, the study used question number 12 in the questionnaire which captures information on the employee affective commitment as the dependent variable while the independent variable was question number 9 which addresses employee performance evaluation done based on laid down standard (objective performance evaluation). In specific term, the Pearson correlation coefficient was 0.72 . This depicts a strong relationship between objective evaluation of employee performance and employee affective commitment. Also, the relationship between objective evaluation of employee performance and employee affective commitment was positive. This implies that the more the performance of employees' in ministries are evaluated based on established standards (objective evaluation), the more the employees increase their affective commitment to their ministries. Based on the above, the study submits that objective evaluation of employee performance has a positive relationship with employee affective commitment. On the other hand, the probability value (P value) of 0.00 was less than the 0.05 maximum significance value for significance. This means that the relationship between objective evaluation of employee performance and employee affective commitment was significant. Therefore, the study rejects the null hypothesis, accepts the alternate and affirms that objective evaluation of employee performance has significant positive relationship on employee affective commitment. 


\section{Hypothesis Two}

Table 4: Pearson correlation result on the relationship between subjective evaluation of employee performance and employee continuance commitment.

\begin{tabular}{ccc}
\hline Pearson correlation coefficient & Probability value & $\mathbf{N}$ \\
\hline 0.09 & $0.13^{*}$ & 257 \\
\hline
\end{tabular}

Source: Researcher's survey, $2018 . /^{*}=$ Significant at $1 \%, 5 \%$ and $10 \%$

Table 4 highlighted the relationship between subjective evaluation of employee performance and employee continuance commitment. For the correlation analysis of relationship, the dependent variable which was captured by question 18 in the questionnaire which addressed employee continuance commitment while the independent variable was captured by question 14 which addressed subjective evaluation of employee performance. Precisely, the Pearson correlation coefficient was 0.09. This depicts that the relationship between subjective evaluation of employee performance and employee continuance commitment was very weak. In other words, subjective evaluation of employee performance has a relationship with employee continuance commitment but the relationship is very weak and unnoticeable which means that there are other variables capable of causing employee continuance commitment than subjective evaluation of employee performance. More so, the probability value ( $\mathrm{P}$ value) of 0.13 was greater than the 0.05 maximum significance value for significance. This means that the relationship between subjective evaluation of employee performance and employee continuance commitment was not significant. Therefore, the study accepts the null hypothesis and concludes that subjective evaluation of employee performance has no significant relationship with employee continuance commitment.

\section{DISCUSSION OF FINDINGS}

From the testing of the first hypothesis, it was established that, objective evaluation of employee performance has positive relationship with employee affective commitment. This supports the finding of the study carried out by Ramous, Lavish, Zipporah and Isaac (2016) which revealed that employee affective commitment is positively related to and impacted by the linkage of appraisals with salary, identification of training needs, clarity of performance appraisal purpose and employee involvement in the formulation of appraisal tools. This is also in line with the finding of the study carried out by Vignaswaran (2008) which shows that there is a relationship between performance appraisal satisfaction and employee outcomes in the form of work performance and affective organizational commitment. This finding is in agreement with Munir, Aziz and Muhammad (2013) contention.

The test of second hypothesis revealed that subjective evaluation of employee performance has a weak insignificant relationship with employee continuance commitment.

\section{CONCLUSION}

This study on performance appraisal and employee commitment in Abia State Civil Service: a focus on Ministries of Education and Works in Umuahia has revealed that objective evaluation of employee performance has a positive relationship with employee affective commitment. This means the more performance of employees of Ministries of Education and Works Umuahia are evaluated objectively, the more employees increase their affective commitment to their Ministries. Furthermore, it was founded that subjective evaluation of employee performance has a weak relationship with employee continuance commitment. This means that there are other variables capable of causing employee continuance commitment than subjective evaluation of employee performance. 


\section{RECOMMENDATIONS}

1. Managers/Directors of public sector should ensure that performance criteria are clearly spelt against which employees at any level of management is appraised to ensure objectivity in the assessment process.

2. Management in their effort to increase employee commitment should look at other variables like reward system, good working environment, leadership style other than performance appraisal.

\section{References}

Ambi, A. (2005). The effects of motivation on job performances in the public: A case study of National Electric Power Authority (NEPA) Kaduna Distribution zone. A Dissertation submitted to department of Business Administration, Faculty of Administration. Ahmadu Bello University. Zaria.

Angelo, S. D., and Robert, D. P. (2006). Management and Organization Review, (2), 253-277.

Anne, W. G., Poti, O. A. and Isaac, O. (2012). Effect of performance appraisal on employee productivity. Asian Journal of Business and Management Sciences Vols. no 11.

Armstrong, M. (2009). Armstrong's handbook of performance management: An evidence- based guide to delivering high performance. UK: Kogan Page.

Asamu, F. F. (2013). Perception of performance appraisal and workers performance in wema bank headquarters. Global- Journal of Arts, Humanities and Social Sciences Vol 1, no 4.

Bard, K. (2006). Performance appraisal satisfaction and employee outcomes: Mediating and moderating roles of work motivation. International Journal of Human Resources Management 17:3 march 2006 504-522.

Baron, R. A (1986). Behaviour in organizations, (2nd ed). Boston: Allyn and Bacon.

Boddy, D. (2008). An introduction to management (4th edition). U.K: Pearson Inc.

Cardy, R. L. and Leonard, B. (2011). Performance management: Concepts, skills and exercises. (2nd). New Delhi: PHI Learning Private Ltd.

Fletcher, C. and Perry, E. (2001). Performance appraisal and feedback: A consideration of national culture and a review of contemporary research and future trends'. In Anderson, N., Ones, D., Sinangil, H. and Viswesvaran, C. (eds) International Handbook of Industrial, Work and Organizational Psychology. London: Sage, pp. 127-44.

Ganta, V. C. (2004). Motivation in the work place to improve the employee Performance. International Journal of Engineering Technology, Management and Applied Sciences.

Grubb, T. (2007). Performance appraisal reappraised: Its not all positive. Journal of Human Resources Education, $1(1), 1-22$.

Hernandez, D. (2002). Local government performance measurement. Public Management, Vol. 84 pp.10-11.

Herzberg, R., Mausner, B., and Snyderman, B. B. (1995). The Motivation to work, (2nd ed), New York: Wiley.

Jackson, S. and Schuler, R. (2002). Managing human resources through strategic partnership (8th ed.). Canada: Thompson Publishers

Jocelyn, M. S. O., Kimanichege, C. and Musiegam O. (2013). Effects of performance appraisal on employee productivity; A case study of Munias Sugar Company limited. International Journal of Innovative Research and Development. Vol2 Issue 9.

Kane, J. S., and Lawler, E. E. (2009). Performance appraisal effectiveness: Its assessment and determinants, in Staw, B. M. (Eds), Research in Organizational Behavior, JAI Press, Greenwich, CT, Vol. 1 pp.425-78.

Levy, P. E. and Williams, J. R. (2004). The social context of performance appraisal: a review and framework for the future. Journal of Management, 30: 881-905.

Lindsey, J. A. (2005). Performance evaluation: A management basic for librarians. Phoenix: Oryx Press,

Manoharan, T. R., Muralidharan, C. and Deshmukh, S. G. (2009). Employee performance appraisal using data envelopment analysis: Research and Practice in Human Resource Management, 17(1), 92-111.

Meyer, H. H. (2001). A solution to the performance appraisal feedback in Nigeria. Academy of Management Executive, Vol. 5 pp.68-76 
Meyer, J. P. and Allen, N. J. (1991). A three component conceptualization of organizational commitment. Human Resource Management Review Vol. 1.

Monday, R. T., Porter, L.W. and Steers, R.M. (1982). Employee organization linkages. New York: Academic press.

Mubbsher, M. K., and Muhammade, K. B. (2012). Employee commitment Vs employee performance effects of employee satisfaction as a moderating variable: A correlational study from Pakistan. Singaporean Journal of Business Economic and Management Studies Vol. 1 no 1.

Munir, S., Aziz, A. and Muhammad, A. M. (2013). Fairness of performance appraisal and organizational commitment. Canadian Center of Science and Education. ISSN 1911-2017 E-ISSN 1911-2025.

Muo, I. K. (2007). Improving the effectiveness of performance appraisal as an evaluative instrument in the workplace. Nigerian Journal of Labour Law and Industrial Relations. Vol.1, N0.3, pp.133-146.

Mwema, N. W. and Gachunga, H. G. (2014). The influence of performance appraisal on employee productivity in organizations: A case study of selected WHO offices in East Africa. International Journal of Social Sciences and Entrepreneurship, 1 (11), 324-337.

Neha, S. and Himanshu. R. (2015) Impact of performance appraisal on organizational commitment and job satisfaction. International Journal of Engineering and Management Sciences Vol 6 (2) 95-104.

Omollo, P. A. (2015). Effect of motivation on employee performance of commercial banks in kenya: A case study of Kenya Commercial Bank in Migori Country. International Journal of Human Resources Studies ISSN 2162-3058.

Onah, 0. (2008). Human resource management. 2nd ed. Enugu: John Jacob’s Classical Publishers.

Onoh, A. N. (2009). The dynamics of organizational behaviour. Enugu: Guzon Ventures.

Panela, A. O (2015). Effect of motivation on employee performance of commercial banks in Kenya. International Journal of Human Resource Studies. ISSN 2162-3058.

Ramous, A., Lavish, M., Zipporah, A. and Isaac, O. A. (2016). The impacts of performance appraisal on employees' job satisfaction and organizational commitment: A case of microfinance institutions in Ghana. International Journal of Business and Management Vol. 11, no 9.

Ramous, Lawish, Zipporah, \& Issac (2016) Revealed that employee commitment is positively related to and impacted by the linkage of appraisals with Salary, Identification of Training needs, clarity of performance appraisal purpose and employee involvement in the formulation of appraisal tools.

Robbins, S. P. and Coulter, M. (2013). Management, eleventh edition. England: Person Education Limited.

Salaman, G., Storey, J. and Billsberry, J. (2005). Strategic human resource management: Theory and practice. ( $2^{\text {nd }}$ edition). Owerri: Sage-publications Ltd.

Shahzadi, J. A., Pirzada, S.S., Nasreen S. and Khanam, F. (2014). Impact of employee motivation on employee performance. European Journal of Business and Management ISSN 2222-2839.

Singh, V. K., Kochar, B. and Yuksel, S. (2010). An empirical study on the efficiency of performance appraisal system in oil and natural gas commission (ONGC). India İşletme Araştırmaları Dergisi 2/2 65-78

Vignaswaran, R. (2008). The relationship between performance appraisal satisfaction and employee outcomes: a study conducted in peninsular Malaysia, submitted to the graduate school of Business faculty of business and accountancy university of Malaya, in partial fulfillment of the requirement for the degree of master of business administration.

Waal, A. D. (2004). Stimulating performance-driven behavior to obtain better results. International Journal of Productivity and Performance Management. pp 315-343.

Yamane, T. (1967). Elementary sampling techniques, Englewood, Cliff, New Jersey: Prentice Hall Inc. 